\title{
7. \\ FEMINIZAM KAO STVARALAČKA \\ PLATFORMA SRPSKIH I HRVATSKIH \\ AVANGARDISTKINJA
}

\section{Žarka Svirčev}

UDK: 821.163.41-055.2:141.72

Izvorni znanstveni članak

Sažetak: U radu se istražuje pozicija feminizma u stvaralačkom iskustvu spisateljica u čijem delu se mapiraju avangardne tendencije. Feministička kontrajavnost u Kraljevini SHS otvorila je tabu teme, posebno teme ženske seksualnosti, telesnosti, materinstva, u nastojanju da izgradi identitet nove žene. Literarno otvaranje i obrada naznačenih tema predstavljaju marker poetičke inovacije i subverzivnosti. Intertekstualne veze avangardistkinja sa feminističkim ideologemama analizirane su na primeru izabranih dela Adele Milčinović, Jele Spiridonović Savić, Mare Ivančan i Olge Grbić, autorki koje su najradikalnije dovele u pitanje tradicionalne društvene narative, oslanjajući se na avangardne strategije pevanja i pripovedanja.

Ključne reči: feministička kontrajavnost, književnost o novoj ženi, avangarda

D

ruštveni potresi i promene koncem Prvog svetskog rata oblikovali su novu paradigmu ženskog autorstva. Godine nakon toga rata obeležene su ne samo procvatom ženskog autorstva, već i uspostavljanjem mreže mikroinstitucija delovanja i saradničke zajednice (serijske publikacije, edicije, uredništva, recenzije i kritika itd.). Socijalne i psihološke zasade promena ženskog stvaralačkog identiteta pružilo je iskustvo Prvog svetskog rata, koje je intenziviralo sazrevanje svesti o ženskim pravima i doprinelo hrabrijem i osmišljenijem nastupu ženskog pokreta na ovim prostorima.

U feminističkoj kontrajavnosti odlučno je iznet zahtev za osvetljavanjem zatomljenih prostora ženskog iskustva diskutovanjem i preoblikovanjem tradicionalnog koncepta ženskih uloga. Novootkrivena ženska subjektivnost zahtevala je nove modele reprezentacije, koji su se ogledali u ideologemama feminističkog diskursa. Neposredno ratno iskustvo i poratno iskustvo feminističkog angažmana i aktivizma stvaralački je bilo izuzetno podsticajno za autorke, pružajući im podršku i modele na različitim planovima, a radikalizam pojedinih od njih koreni se upravo u njemu. Radikalizam na planu otvaranja tema, odnosno ideoloških njihovih implikacija, koje su se kod pojedinih autorki podrazumevale, sustiče se s eksperimentom i inovacijom na formalnom planu. 
Ratni diskurs i ratna trauma prepoznati su kao činioci od prvorazrednog značaja za formiranje evropske modernističke i avangardne svesti i senzibiliteta, grupne dinamike i retorike, te poetičkih toposa. Međutim, ono što je u osnovi još uvek vitalnog koncepta modernizma i avangarde jeste retorika patrijarhalnog maskuliniteta (iako je on sam bio predmet dubinskih prekrajanja) $\mathrm{i}$ isključivo muškarčevo iskustvo rata kao epistemološki povlašćeno i poetički konstitutivno.

Revizionistička čitanja računaju na različite zone iskustva i doživljaja (a ne samo rovovsko), podrazumevajući uključivanje šireg korpusa tekstova u istraživanje i promišljanje avangarde, što je čini mnogolikijom no što smo navikli. Takvom je čini i izranjanje potisnutih stvaralačkih iskustava, odnosno usmeravanje pažnje ka isključivo ženskom iskustvu kakav je bio feministički aktivizam - koji je takođe jedna od posledica Prvog svetskog rata, koja je dovela do manifestacije pojedinih avangardnih tendencija. Spisateljice su „poetiku osporavanja" gradile oslanjajući se na emancipatorske i feminističke ideologeme svoga vremena, koje su za njih bile formativne na način na koji je rat motivisao uvođenje pojedinih tematsko-motivskih jedinica, formalnih postupaka i žanrovskih inovacija.

Feministička periodika nakon Prvog svetskog rata mesto je na kom je ponajpre došlo do intenzivnog preplitanja naučnog, publicističkog, esejističkog i literarnog diskursa o oblikovanju novog identiteta žene. Stanislava Barać pokazala je da je izgradnja društvenog identiteta nove žene bila glavni, ali i najudaljeniji cilj feminističke kontrajavnosti. ${ }^{1}$ Autorke su se, dakle, idejno približavale ili oslonac nalazile u najuticajnijoj feminističkoj ideologemi, ideologemi nove žene. Iako je ona ponikla u britanskoj i nemačkoj štampi krajem XIX veka, njen prototip u jugoslovenskoj feminističkoj kontrajavnosti predstavlja studija Aleksandre Kolontaj Novi moral i radnička klasa (1919.) čiji je prevod, pod naslovom Nova žena, objavljen 1922. u Kraljevini SHS. Distinktivne crte nove žene koje Kolontaj izdvaja - ume da savlada osećanja, postavlja sve veće zahteve svom mužu, ne trpi despotizam, ekonomski je samostalna, rad i stvaralaštvo postaju joj značajni životni sadržaji, prihvata novi seksualni moral - teorijski je model prema kojem se upravljao feministički diskurs u Kraljevini SHS. ${ }^{2}$

Barać je uočila sponu između publicističkog žanra ženskog portreta i književnih tekstova koji prikazuju ideologemu nove žene, izdvajajući specifičan korpus tekstova u jugoslovenskoj međuratnoj književnosti - književnost o novoj ženi. ${ }^{3}$ Reč je o žanrovski raznolikim tekstovima koje su pisale uglavnom žene o emancipovanim ženama (ili njenom negativu) kao glavnim junakinjama, za pretežno žensku čitalačku publiku. To su, uglavnom, tekstovi koji su nastajali kao odgovor na javne debate pokrenute u feminističkoj kontrajavnosti, u kojima su detabuizirane određene teme i u kojima je istraživano zapostavljeno žensko iskustvo.

Zahtev za oslobađanjem i tematizacijom potisnutih ženskih iskustava iziskivao je prekoračivanje niza granica, ponajpre „ubijanje anđela u kući“ (Virdžinija Vulf), odnosno preva-

\footnotetext{
Станислава БАРАћ, Феминистичка контрајавност: жанр женског портрета у сриској периодищи 1920-1941., БеограА 2015., 97.

2 Isto, 103.

3 Isto, 289-230.
} 
zilaženje (samo)nametnutih cenzura u sferi imaginacije. Imaginacijsko oslobađanje je, čini se, najprovokativnije i najizazovnije bilo postići u sferi tela, žudnje, erotike. $S$ obzirom na to da nova žena prihvata novi seksualni moral, ono što je bio zadatak književnosti o novoj $\check{z ̌ e n i ~ j e s t e ~ i s p i s i v a n j e ~ v e l i k o g ~ k o n t r a n a r a t i v a ~ o ~ k l j u c ̌ n i m ~ i n s t i t u c i j a m a ~ d i s c i p l i n o v a n j a ~(„ n a d-~}$ ziranja i kažnjavanja") ženskog tela - o braku i materinstvu.

U detabuizaciji telesne samosvojnosti, neposlušnosti i ekscentričnosti najdalje su se otisnule autorke koje su se na poetičkom planu približile avangardnim tendencijama. Jer, inovacije koje oslobađaju od tradicionalnih poetičkih modusa nesumnjivo su bile podobne za artikulaciju novoga modela ženskog iskustva. Stepen, odnosno područje intime koje se razotkriva jeste poetički marker: smeli tematski iskoraci poklapali su se sa formalnim oneobičavanjima svojstvenim avangardnim poetikama.

Godine 1919., kada objavljuje kratak roman Sjena, Adela Milčinović je već afirmisana autorka, izrazito feministički angažovana. Bila je prepoznatljiva po literarnoj obradi feminističkih tema, „istražujući suptilnu dramu muških i ženskih veza, najviše zastrašujući zid među spolovima, simbol njihova nesporazuma prouzročena različitošću“. ${ }^{4}$ Detoni-Dujmić je pojedine aspekte romana Sjena stilsko-figuracijski situirala u okvire avangardnog pripovedanja, izdvajajući postupak simbolizacije (sena) koji vodi antiestetizmu, opise haotičnih gradskih prizora, kao i prožetost saznajnih analiza banalnim i bizarnim elementima. ${ }^{5}$

"Zid među spolovima“" u Sjeni ponajviše je uzrokovan jezičkim raskolom, sudarom oprečnih jezičkih režima supružnika. Nad govorom Vide, glavne junakinje, vrši se represija, ona je uhvaćena u jezičku zamku:

I najljepša stvar, kada je bila izrečena, izgubila je za nju vrijednost, čar. Ona je imala samo osjećaje i njoj bijahu osjećaji sve. Oko, prsti, kretnje, to bijaše za nju ono, što je drugima jezik. ${ }^{6}$

Iako joj je fantazija bila bujna i živa, čula osetljiva i širokog raspona, „riječi su njene bile suhe i siromašne, da izraze ono, što je živjelo u njenoj duši “7 Deviza njenog supruga bila je „svaka misao mora postati riječju“, a ukoliko bi Vida odbila da se izrazi ili bila nemoćna da to učini, on bi „stao pričati, kako čovjek mora svaki svoj osjećaj, svaku misao do u tančine raščiniti, kontrolirati svaku sitnicu“. 8

Nemogućnost izražavanja vodi u podvojenost:

Vazda su u njoj bila dva bića. Jedno je bilo ona, njezina duša, a drugo njezina vanjština. I kad god se je tako promatrala, vidjela je jasno jednu spodobu u željeznoj odjeći, zakopčanoj do grla, hladnoj i krutoj - ali pod tom je željeznom odjećom osjećala vruću krvcu, kako teče, mišice, kako se stežu i grče, srce koje vruće bije i osjeća, ${ }^{9}$

\footnotetext{
Dunja Detoni-Dujmić, „Predgovor“, u: Adela Milčinović, Izabrana djela, Zagreb 1997., 247.

Isto, 251.

A. MilčInović, Sjena, Zagreb 1997., 306.

Isto.

Isto, 308.

Isto, 307.
} 
a ta spodoba neprestano vreba svaki njen korak i pokret, svaku njenu misao. Vida je pokušala da se primora i da uvaži muževljeve savete - „ona je naučila govoriti, naučila je zatvarati uši, da ne sluša svoj glas, naučila je pomalo otvarati ventile svoga mozga", ponavljajući sebi „moje su oči slabe, moram da se naučim gledati u sunce“. ${ }^{10}$ Međutim,

ona čezne za dubinama. Privlače ju i mame k sebi i ona zatvara oči, pa se baca naglavce u jezero - $\mathrm{i}$ brzo opet izroni na površinu. Kosa joj je mokra i ona strese glavom, a kapljice pršte oko nje; skida sa sebe vodene trave i gleda velike kolobare, koji kruže oko nje. A usne su joj modre i tijelo joj se strese od mraza, a ona se smije, smije. ${ }^{11}$

Disocijaciju ženskog subjekta usled nemogućnosti samoreprezentacije u logocentričnom jeziku koji joj nameće suprug, te naslućivanje alternativnih označavalačkih praksi, možemo čitati i na fonu poststrukturalističkih koncepata, ženskog pisma Elen Siksu i opozicije simboličko/semiotičko Julije Kristeve. Jer, brojni nesporazumi između Vide i njenoga supruga rezultat su njegove vere u „metafiziku prisustva“, a Vidina jezička izmeštenost osvedočava da u falocentričnoj kulturi ne postoji jezik za ono što je marginalizovano. Ritam Vidinog tela i nesvesnog ne podleže zahtevima simboličkog i stoga ostaje van jezika, a njena psihološka pobuna vodi ka drugačijim komunikacijskim obrascima.

Potreba za alternativnim jezičkim režimima nije upisana u samu jezičku strukturu teksta, odnosno Milčinović se nije okrenula eksperimentalnoj označavalačkoj praksi. Međutim, ako i nije eksperimentisala sa jezičkim znakom, jeste sa narativnim perspektivama. U narativnoj transgresiji u tom su se trenutku okušale samo Isidora Sekulić i Milica Janković. Raskid sa sopstvenom prirodnom gramatičkom kategorijom roda u ime muškog govornog subjekta u 1. licu Magdalena Koh nazvala je „rodni diskurs u akciji“, prepoznajući u tome postupku prilično ekstravagantnu proceduru kršenja važećeg spisateljskog koda, svesno sukobljavanje sa ograničenjima i determinizmom vlastitog biološkog pola, nomadski identitet subjekta i njegovu podvojenost između ličnog izbora i nametnute pripadnosti, zaključujući da se jezik spisateljica nije zatvarao, već je omogućavao pogled u druge predele iskustva. ${ }^{12}$

Narativnom transgresijom artikuliše se glas osakaćenog muškarca, takođe marginalizovanog u hijerarhiji društvene moći i njene reprezentativnosti. Poetika prijateljevih epistolarnih beležaka - fragmentarna struktura, eliptična rečenica, retorički naboj, izrazita introspekcija, fokus na halucinantna stanja, asocijativna skokovitost i digresivnost - korespondira sa stanjem svesti decentriranog subjekta. Međutim, kroz tekstualne pukotine progovara prijateljevo telo, i to ne jezikom patnje, traume ili perverzije, kako je uobičajeno kodifikovan trup u ratnoj prozi, već je to telo koje oseća želju, vitalistički i erotski naboj, ugrožavajući time paradigmatični maskulinitet koji ženi ne može da pruži užitak. Vida uspostavlja komunikaciju intimne prirode sa pokojnim prijateljem, njegovom senom. Njihova komunikacija, koju suprug oseća i o kojoj svedoči, i koja ga vodi u stanje rastrojstva, van domašaja je racionalne spoznaje, čiji se, u suštini, civilizacijski učinci i problematizuju u ovom romanu.

10 Isto, 310 .

11 Isto, 311.

12 Магдамена Кох, ...када сазремо као култура... Стваралаштво српских списатељица на почетку ХХ века (канон -жанр-род), БеограА 2012., 250-252. 
Diskurs tela i libidalne energije poetička je dominanta stihova Jele Spiridonović Savić, objedinjenih u zbirci Sa uskih staza (1919.). Onovremena kritika nije mogla da ne reaguje na subverzivni karakter tih stihova. Milan Bogdanović ističe, prikazujući nove knjige u Politici 1919. godine, da u Zagrebu, oko Krležinog Plamena, Miloš Crnjanski i Jela Spiridonović Savić skandalizuju svojim stihovima. ${ }^{13}$ Versološka neposlušnost i okretanje slobodnom stihu i „ritmu ekstaze“ (M. Crnjanski), te novi tip osećajnosti i čulnosti tačke su kritičkog napada na Liriku Itake Miloša Crnjanskog u ranoj fazi njene recepcije, a vredi spomenuti da je prvi afirmativan prikaz zbirke napisala upravo Jela Spiridonović Savić. Ako je muškarac prevazišao „horizont očekivanja“ javnosti i čitalačke publike, a danas Liriku Itake i razumevamo kao jednu od onih zbirki koja je inicirala novi poetički diskurs, možemo samo da pretpostavimo prirodu i intenzitet reakcije na srodan izgred žene čija je prva pesnička zbirka u današnjoj književnoj istoriografiji potpuno skrajnuta.

Izdvajajući tri ciklusa pesama u zbirci, deskriptivni, refleksivni i feminološki, Jovana Reba druga dva ciklusa poetički približava avangardnim tendencijama, nalazeći u njima ekspresionističke elemente: „ekstatični doživljaj sveta, intuitivnost religiozne spoznaje, metafizička identifikacija sa kosmosom, individualizam u smislu odvajanja od licemernog građanskog društva i potraga za suštinom stvarnosti u neistraženim dubinama sopstvenog bića“. ${ }^{14}$ Međutim, autorka naglašava da, iako se „svetlost prvog talasa srpskog ekspresionizma prelama u lirskom prvencu Jele Savić“, ono što ga odvaja od dela savremenika jeste „upitanost nad polifonijom značenja misticizma“ koja „izoluju njenu poeziju od uticaja dramatičnih društvenopolitičkih potresa" koji su obeležili poeziju njenih savremenika. ${ }^{15}$

Ponuđena interpretacija više je motivisana autorkinom željom da potvrdi svoju hipotezu - glorifikacija hrišćanske ljubavi i njeno oslobađanje od polnih obeležja kao pesnikinjina dominantna potreba ${ }^{16}$ - no što uspeva da obuhvati širok raspon, koji uključuje niz oprečnosti, sužavajući semiozu poetske zbirke. Društveno-političke potrese poetski tekstovi Jele Spiridonović Savić seizmički beleže, upisujući ih u frakturu svoga stiha i njegov ritam, stav i bunt lirske junakinje, i njen trajektorijum, socijalni aktivizam, te napeti odnos između čulnog i natčulnog, koji se ne razrešava. Feminizam se ukazuje kao društveno-politički fon na kojem se odvija ikonoklastija Jele Spiridonović Savić.

Pesnikinja „raskošne mašte i vrelog temperamenta“, „velikog osećanja ploti i krvi i jakih čulnih senzacija ${ }^{\text {"17 }}$ u zbirci Sa uskih staza slobodno opeva erotski užitak žene, odnosno želju za nesputanim erotskim užitkom, bilo da je zaodeva u alegorijske slike ponikle u narodnoj lirskoj pesmi ili molitveno-himnično obraćanje željenom. Muškarac je u stihovima sinegdohično fragmentizovan; njegove oči, usne, ruke ambivalentno su kodirani, oni su i izvor zadovoljstva lirske junakinje i izvor njene anksioznosti, oni se združuju sa vitalističkim nabojem i užitkom u čulnosti, ali su upisani i u raskole i disonantnosti. Užitak je povezan i

\footnotetext{
13 Милан БогАановит, „Нове књиге“, Политика (БеограА), бр. 4265, 16. $12.1919 ., 1$.

14 Јована РевА, „Мистика Јеме Спиридоновић Савић“, у: Јема Спиридоновић САвић, Вечите чежне, БеограА 2012., 283.

15 Isto.

16 Isto, 285.

17 Миман КАшАнин, „Три књиге песама“, Aemonuc Mamuue cpncke, 311/1927., бp. 1-2, 205.
} 
sa bolom i sa blaženstvom, lirska junakinja poseže i za čulnim i natčulnim kao utočištem, u pojedinim stihovima erotika dobija metafizički prizvuk, ali je u pojedinim stihovima lišena transcendentnog naboja.

U Pesmi čula, koju možemo posmatrati kao programsku - prepoznajući u njoj objavu nove ženske subjektivnosti - artikuliše se čežnja za totalnim užitkom, za intenzivnim doživljavanjem života čije se svakodnevno iskustvo estetizuje. Najradikalniji zahvat pesnikinja/lirska junakinja vrši u poretku čulnosti, odnosno reteritorijalizaciji ženskog iskustva. Reč je o pesmi probuđenih, osvešćenih ženskih čula: opevajući iskustvo svih pet čula (vid, sluh, miris, dodir, ukus) lirska junakinja povišenim tonom zahteva nove predele iskustva posredovanih određenim čulima. Već u prvim stihovima ona raskida sa socijalnim konvencijama upisanim u čulo vida, ističući „hoću da vidim željom dubokom i žednim okom“. Prodorni pogled žednog oka ženski subjekat istovremeno smešta na poziciju šetača (flâneur) i putnika, ukidajući opoziciju privatno/javno, opresivnu po ženin identitet. Takođe, žedno oko ukida patrijarhalni stid i pasivnost, rezervisane za ženu u ljubavnoj igri, implicirajući, glagolom zariti, stepen bliskosti i intenzitet kontakta, te inicijativu i odlučnost: Hoću da gledam / visinu nebeskog svoda / i beskrajnu pučinu mora, / (...) I voljeni moj, / hoću da zarijem / oči moje / u oči tvoje. ${ }^{18}$

Telo postaje privilegovano mesto iskustva, ono nije odeljeno od duha, već je zajedno sa procesualnošću i životom u svojoj ukupnosti preduslov spoznaje. Nižući sopstvene želje oposredovane određenim čulima, lirska junakinja zahteva potpunu slobodu i želje i užitka: I vrelim dahom / hoću da udišem / mirise što zanose / (...) Od pokošena sena / i krunica cveća I posle kiše / ali još više / mirise lažne, / koji se širi / s raskošnih tela / i odela / mladih, čežnjivih žena. ${ }^{19}$ Revizionističko čitanje i prevrednovanje konstitutivnih vrednosnih opozicija evropske građanske kulture (privatno/javno ili priroda/kultura) posredovano je ženskim telom koje postaje i polje epistemološkog zrenja i intenzivnog užitka.

Tokom dvadesetih godina spisateljice su nastavile, odlučnije i radikalnije, da problematizuju velike narative građanskog društva, u čijem središtu je žensko telo, ukrštanjem avangardnih narativnih postupaka i reprezentacijskih elemenata svojstvenih ideologemi nove žene. Najdalje u obradi lika nove žene, odnosno zahteva novih žena, otišle su Mara Ivančan u romanu Čudnovata priča (1924.) i Olga Grbić u romanu Sudbina Vere Petrovićeve, u čijem podnaslovu je ispisano Filmski roman za bludnice čistih duša i za čestite žene neciste savesti (1925.). ${ }^{20}$

U romanu Čudnovata priča Ivančan obrađuje dve tabu teme. Već na samom početku romana dobijamo informacije o dominantnim osobinama Marije Katićeve, glavne junakinje: ona je „egzaltirana“, samosvesna i samosvojna, otresita i prkosna, ali i nervozna. U daljoj karakterizaciji možemo prepoznati „peti tip“ junakinje o kojoj je pisala Aleksandra

18 Ј. СПиридоновић Савић, Са уских стаза, Београд 1919., 61.

19 Isto, 63.

20 Romani Mare Ivančan i Olge Grbić poetički su vrlo srodni, odnosno bliski su poetici kratkog avangardnog romana, s tim da se prednost u kvalitativnom smislu mora dati Mari Ivančan: preplitanje različitih diskursa (polemički, lirski, te vizije i halucinacije), opredeljenje za sižejnu, a ne fabularnu prozu, načelo montaže, alegorijska fantastika, subjektivizacija i manipulacija vremenom, samorefleksija narativnog postupka, intimizirana narativna perspektiva, žanrovsko raslojavanje. 
Kolontaj, tip „,neudate žene“: ,junakinje sa samostalnim zahtevima na život, junakinje, koje svoju ličnost dokazuju, junakinje koje protestvuju protiv opšteg zarobljavanja žene u državi, porodici, društvu, koje se bore za svoja prava kao predstavnice svoga pola“. ${ }^{21}$ Ono za šta se Marija Katićeva bori jeste pravo na vanbračni seks i materinstvo van braka - tabu teme otvorene i u jugoslovenskoj feminističkoj kontrajavnosti.

Marija Katićeva dosledno depatetizuje i demistifikuje ljubavni diskurs, insistirajući na uživanju u muškom telu i njegovoj snazi, prenebregavajući druge aspekte potencijalne veze. Ona ne skriva svoje telesne nagone, ne odriče se „zemaljskih radosti“, a „pobuna žene protiv jednostranog seksualnog morala jeste jedna od najoštrijih karakteristika nove junakinje“.22 Polemički diskurs, koji prožima okvirnu priču, motivisan Marijinom odlukom o vanbračnom materinstvu, eksplicitno je poduprt feminističkim idejama.

Takođe, već na samom početku romana uvodi se motiv ludila: Marijini odlučni zahtevi za samostalnošću okvalifikovani su kao plod histerije. Histerija je jedna od ključnih karakteristika reprezentacije feministkinja od poslednjih decenija XIX veka do početka Prvog svetskog rata, kada se i odvija radnja romana. Razmatrajući odnos histerije, feminizma i roda, Ilejn Šouvolter je zapazila poklapanje razvoja medicinskog diskursa o histeriji, odnosno njene feminizacije s usponom feminizma i ideologeme nove žene krajem XIX veka. ${ }^{23}$

U romanu je, pored feminizacije histerije, važna i ideja o njenoj uslovljenosti položajem žene u patrijarhalnoj kulturi:

Marija nije nikom govorila o sablastima koje je snivala. (...) Bila je ekscentrična i strašljiva, a koja to žena nije? Izuzev one koje imadu posve zdrave i posve normalne jajnike i živce. A koje žene to imadu, kad od najranijih godina, decenije svog života sprovode sjedećki u uredima. ${ }^{24}$

Odbrana histerije predstavlja odbranu ženske nepokornosti, te podršku njenoj borbi za slobodu. Čak, histeriju možemo čitati na način na koji je feminizam razumevao histeriju počevši od 70-ih godina: kao govor ženskog tela protiv patrijarhata, feministički protojezik: ${ }^{25}$

"Vi imate lijepih ideja, tek, kao da su vam živci malo oboljeli.“

„Možda se moji živci, zato što su osjetljiviji od vaših i od živaca ostalih ljudi, smiju nazvati i bolesnim, no ja sam uvjerena da za veliku ideju i trebaju uvijek ovako bolesnih živaca, a to možda i jest nesreća čitavog čovječanstva. Ako žena brani svoju slobodu..." ${ }^{26}$

Međutim, ludilo Marije Katićeve nakon porođaja otvara niz pitanja koja onemogućavaju završnu interpretativnu reč, bar ne onu samodovoljnu. Majčinstvo je, poput ljubavi, deromantizovano i depatetizovano. S njim su blisko skopčane strepnja, anksioznost, ugroženost

\footnotetext{
Александра Колонтај, Новажена, БеограА 1922., 5.

22 Isto, 34.

23 Elaine Showalter, „Hysteria, Feminism, and Gender“, Hysteria Beyond Freud, Berkeley - Los Angeles - Oxford 1993., 306.

24 Mara Ivančan, Čudnovata priča, Zagreb 2004., 19.

25 Više o tome u navođenom tekstu Ilejn Šouvolter.

26 M. IvanČAn, Čudnovata priča, 24-25.
} 
i patnja. Trudnoća i porođaj radikalno menjaju ženinu poziciju - Marija nakon porođaja postaje domaćica, vezuje se isključivo za privatnu sferu. Da li je Marijino ludilo znak pobune protiv patrijarhata i njene nepodesnosti za ulogu majke? Da li je reč o potvrdi da je društvo još uvek nedovoljno emancipovano za samohrane majke ili, pak, da žene nisu dovoljno emancipovane da ponesu teret vaninstitucionalnog majčinstva? Mariji je san pružio uvid u majčinstvo, a slom nakon sna i porođaja možda je odbijanje vršenja uloge majke u patrijarhalnom društvu, povlačenje u sebe i tišinu, autonegacija i dezintegracija kao jedini vid bekstva. Da li je reč o negaciji ili potvrdi tradicionalnih normi - ostaje otvoreno pitanje.

Suprotstavljeni društveni narativi oblikuju i Sudbinu Vere Petrovićeve. Roman prati ljubavne, odnosno erotske avanture glavne junakinje, Vere Petrović, u potrazi za idealnom ljubavlju koja će kulminirati brakom. Od prve, slučajne erotske epizode petnaestogodišnje Vere, u kupeu, s nepoznatim vojnikom, preko ljubavnih doživljaja sa muškarcima različitih profila, interesovanja i namera, do poslednje ljubavne avanture koja seže do krajnosnih granica, pratimo sazrevanje Verinog antropološkog pesimizma.

Vera Petrović je nova žena u nastajanju jer ona, s jedne strane, pokazuje izrazitu emancipovanost u pogledu seksualnosti, ali, s druge, identitet izgrađuje isključivo u odnosu sa svojim ljubavnicima, iscrpljujući vrednost i smisao života u tim odnosima. Naratorka, za razliku od Vere Petrović, jeste feministički osvešćena, ona je ta koja, prateći sudbinu Vere Petrovićeve, komentariše, osuđuje, polemiše, ironiše i parodira tradicionalne i represivne društvene norme, ljubavne, odnosno književne konvencije, artikulišući pobunu protiv patrijarhalnog morala, protiv licemerja, zahtev za potpunom autonomijom i slobodom. Vera je žrtva i sopstvenih izbora, odnosno ideala (sa stanovišta naratorke i ideologeme nove žene - anahronih) i društva u kojem živi.

Olga Grbić je u tematizaciji ženskog seksualnog oslobađanja najdalje otišla. Njena junakinja istražuje sopstvenu seksualnost, a erotika je prikazana u rasponu od hedonističkovitalističke igrivosti do demonskog plesa i tanatoloških dimenzija:

Svaka misao koju je ona izvodila iz svesti u mozak, rasplinula bi se u nešto žarko, crveno, bez forme i bez sadržaja. Ona je teško disala, osećajući Aleksandrovu blizinu kao prisustvo neke aveti, koja će joj svojim pokretima otvoriti žile na vratu i ispiti joj svu krv. Videla je kao u magli kako joj se ta avet primiče i kako joj se ovija ruka oko tela. Osećala je neku strašnu snagu, koja hoće da joj raskine noge. Avet joj je zatvorila usta snažnim i gorućim pritiskom. To je bio poljubac ljubavnog ludila. Sav telesni život prešao je na kožu Verinog tela. Ona je sva gorela i osećala svaki dah, svaki val vazduha i sve struje strasti. Mozak joj je izgoreo od užasa i neopisivog uživanja. ${ }^{27}$

Verovatno je upravo navedeni odlomak bio jedan od razloga da kritičar romana, u tekstu objavljenom u izuzetno uticajnom ženskom časopisu, potpuno skandalizovan romanesknim izgredom Olge Grbić, traži od čitalaca dopuštenje da iz ovog romana ne citira ništa, jer „bio bih u neprilici“, i apeluje da se žene „obuku“ i ostave muškarcima „bar koju iluziju“ (nije precizirao čega). ${ }^{28}$

\footnotetext{
27 ОАга Грьић, Судбина Вере Петровићеве, БеограА 1925., 37.

28 Ник., „Покрите се!“", Жена и свет, 1/1925., 6р. 10, 4.
} 
Nakon što ju je ostavio ljubavnik s kojim je doživela ultimativno iskustvo, Vera Petrović ludi i ljubavnika ubija. Verin solipsizam nas unekoliko onemogućava da njen pucanj, iako se naposletku identifikuje sa svim obespravljenim i poniženim ženama, bez ostatka razumevamo kao pucanj u društveno telo, a njeno ludilo kao manifestni iskaz feminističkog militantizma, jer se isti taj pucanj može tumačiti kao izraz njene nemoći i kapitulacije. Čak ni motiv inkubusa (Verin poslednji ljubavnik nedvosmisleno poprima osobenosti demonskog ljubavnika) ne doprinosi interpretativnom razrešenju jer, shodno tradiciji zapadnoevrpskog folklora, Vera bi seksualnim činom sa njim i sama poprimila nadnaravne moći, izopštavajući se svojevoljno iz društvenog poretka. Međutim, odgovor na pitanje da li je zaposednutost „višom silom“, odnosno fantastički motiv, kao i u slučaju Čudnovate priče, relevantno tumačiti socijalnom kodiranošću ili ga naprosto treba prenebregnuti u razumevanju (pro) feminističkih značenja teksta - iziskuje opsežnije istraživanje.

Destabilizacija tradicionalnog rodnog identiteta i istraživanje seksualnosti svojstveno je podjednako i avangardistkinjama i avangardistima, $s$ tim da su ženu naglašene čulnosti i oslobođene seksualnosti autorke afirmisale u svom delu, a uporište su imale u feminističkoj kontrajavnosti i ideologemi nove žene. Ipak, u njihovom delu se i dalje odvija agon suprotstavljenih društvenih narativa, seksualnost je ambivalentna, a identitet žene nekoherentan. U međuratnom periodu nova žena nije indukovana iz realnosti, ona je medijska konstrukcija, ideal za koji se bori. ${ }^{29}$ Otuda i lomovi, nedoslednosti, izmeštenost, sumnja i kriza u borbi za identitet nove žene, a avangardna forma nametnula se kao najpodesnija i za priču o ženskom.

\section{$\cos$}

\section{Feminism as the CREative Platform of Serbian and Croatian AVANTGarde Writers}

Feminism was formative for the women writers who stepped onto the Yugoslav literary scene at the end of World War I and in the early 1920s. These women writers articulated their feminist commitment in various ways, either through essays (that is, their literary work) or through direct activism (through contributing to magazines, working with organizations, participating in congresses, etc.), which intensified in the newly-formed Kingdom of Serbis, Croats and Slovenes. They chose it as an integral part of their cultural and intellectual identities. Feminism is postulated as a point of poetic origin for the women writers whose work included mapping out avantgarde tendencies - that is, it is postulated as a crucial element of their creative identity. The poetic implications of the literarization of feminist ideas are evident on the thematic and the lexical-formal levels. The women writers maintained the closest intertextual interaction with the most influential feminist ideologeme of the time, that of the New Woman. Since the New Woman advocated a new kind of sexual morality, the task of writing about the New Woman involved contributing to the creation of the great counter-narrative of the institutions key to disciplining (surveiling and punishing) the

29 С. БАРАћ, Феминистичка контрајавност, 105. 
female body: marriage and motherhood. The women writers who went the furthest in lifting the taboo off physical disobedience and eccentricity, as well as female sexual desire, were those who, in terms of poetics, came nearest to avantgarde tendencies - Jela Spiridonović Savić, Adela Milčinović, Mara Ivančan and Olga Grbić.

Key words: the feminist counterpublic, New Woman fiction, the avantgarde

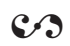

\section{Literatura}

Станискава БАрАћ, Феминистичка контрајавност: жанр женског портрета у српској периодищи 1920-1941., БеограА 2015.

Миман БогААновић, „Нове књиге“, Политика (Београд), бр. 4265, 16. 12. 1919., 1-2.

Dunja Detoni-Dujmić, „Predgovor“, u: Adela Milčinović, Izabrana djela, Zagreb 1997., 245257.

Омга Грьић, Судбина Вере Петровићеве, Београд 1925.

Mara IvanČAn, Čudnovata priča, Zagreb 2004.

Миман КАшАнин, „Три књиге песама“, Аemonuc Mamuще сpncke, 311/1927., бp. 1-2, 204-207.

Магдацена Кох, ...када сазремо као култура... Стваралаштво српских списатељища на почетку ХХ века (канон-жанр-род), БеограА 2012.

Александра Коцонтај, Нова жена, Београд 1922.

Adela Milčinović, Sjena, Zagreb 1997.

Ник., „Покрите се!“, Жена и свет, 1/1925., бр. 10, 4.

Јована РебА, „Мистика Јеле Спиридоновић Савић“, у: Јела Спиридоновит Савит, Вечите чежнье, БеограА 2012., 283-303.

Elaine Showalter, „Hysteria, Feminism, and Gender“, Hysteria Beyond Freud, Berkeley - Los Angeles - Oxford 1993.

Јема Спиридоновит САвит, Са уских стаза, Београд 1919. 